\title{
Micronutrients: A Current Status and its Symptoms on Crops
}

\author{
Rakesh Giri Goswami*1 ${ }^{1}$ Thaneshwar Kumar ${ }^{2}$, Ashish Kumar Singh ${ }^{3}$, Surbala Painkra ${ }^{4}$ \\ ${ }^{1,2,3} \mathrm{Ph}$.D. Rearch Scholar Department of Soil Science and Agricultural Chemistry \\ ${ }^{4}$ PG Scholar Department of Floriculture and Landscape, Indira Gandhi Agricultural University, Raipur -492012 (C.G), INDIA
}

\begin{abstract}
Micronutrients are essential for the normal growth of plants. Deficiencies of micronutrient drastically affect the growth, metabolism and reproductive phase in plants, animal and human beings. Wide spread deficiencies of micronutrients has been found in Indian soils. About 3 billion people in the world are affected with micronutrient malnutrition. Crop plants requires 17 nutrient elements viz. $\mathrm{C}, \mathrm{H}, \mathrm{O}, \mathrm{N}, \mathrm{P}, \mathrm{K}, \mathrm{Ca}, \mathrm{Mg}, \mathrm{S}, \mathrm{Fe}, \mathrm{Cu}, \mathrm{Mn}, \mathrm{Zn}, \mathrm{B}, \mathrm{Mo}, \mathrm{Cl}$ and $N i$ for completing their life cycle. Out of these last eight elements are micronutrients that are needed in very less amount for crops but these are equally important as that of macronutrients. Management of micronutrients deficiencies in view of decline in production of major crops is a cause of concern that requires immediate attention. Production of adequate food grain from the finite land resources to feed the burgeoning population is a great challenge in the years to come.
\end{abstract}

Keywords - Essential element, Micronutrient, growth, metabolism, symptoms.

\section{DEFICIENCY OF MICRONUTRIENTS}

Changing scenario of micronutrient deficiencies phase wise during four decades (1968-2008) was studied in soils of India, their impact of crop production and changes in micronutrient concentration in seeds and fodders, thereby influences on animal and human health. Scenario of micronutrient deficiency in north India in early eighties was different than now after four decades. Zinc deficiency remained a major problem all over country. Zinc deficiency has increased from $44 \%$ to $48 \%$ and expected to further increase up to $63 \%$ by 2025 as most of the marginal soils are showing higher response to added zinc (Singh, 2006). State wise scenario of soils tested deficient in micronutrients (Table 1) revealed that $\mathrm{Zn}$ deficiency was mainly associate with the states of Maharastra (86\%), Karnataka (72\%), Haryana (60\%), Tamilnadu (58\%), Orissa (54\%), Bihar (54\%) and U.P. (45\%). Whereas B deficiency is widespread in West Bengal (68\%), Bihar (38\%), Karnataka (32\%), U.P. (24\%), M.P. (22\%) and Tamilnadu $(21 \%)$.

Table.1: State wise scenario of Soils tested deficient in micronutrients

\begin{tabular}{|c|c|c|c|c|c|}
\hline $\mathbf{Z n}$ & B & $\mathbf{F e}$ & Mn & $\mathrm{Cu}$ & Mo \\
\hline $\begin{array}{c}\text { Maharastra } \\
(86 \%)\end{array}$ & $\begin{array}{c}\text { West Bengal } \\
(68 \%)\end{array}$ & $\begin{array}{c}\text { Karnataka } \\
(35 \%)\end{array}$ & $\begin{array}{c}\text { Meghalaya } \\
(23 \%)\end{array}$ & $\begin{array}{l}\text { Tamilnadu } \\
(6 \%)\end{array}$ & $\begin{array}{c}\text { Haryana } \\
(28 \%)\end{array}$ \\
\hline $\begin{array}{c}\text { Karnataka } \\
(72 \%)\end{array}$ & $\begin{array}{l}\text { Bihar } \\
(38 \%)\end{array}$ & $\begin{array}{l}\text { H.P. } \\
(27 \%)\end{array}$ & $\begin{array}{l}\text { Assam } \\
(20 \%)\end{array}$ & $\begin{array}{c}\text { Karnataka } \\
(5 \%)\end{array}$ & $\begin{array}{l}\text { M.P. } \\
(18 \%)\end{array}$ \\
\hline $\begin{array}{c}\text { Haryana } \\
(60 \%)\end{array}$ & $\begin{array}{c}\text { Karnataka } \\
(32 \%)\end{array}$ & $\begin{array}{c}\text { Maharastra } \\
(24 \%)\end{array}$ & $\begin{array}{c}\text { Karnatak } \\
(17 \%)\end{array}$ & $\begin{array}{c}\text { Gujrat } \\
(4 \%)\end{array}$ & $\begin{array}{l}\text { Gujrat } \\
(10 \%)\end{array}$ \\
\hline $\begin{array}{c}\text { Tamilnadu } \\
(58 \%)\end{array}$ & $\begin{array}{c}\text { U.P. } \\
(24 \%)\end{array}$ & $\begin{array}{c}\text { Haryana } \\
(20 \%)\end{array}$ & $\begin{array}{l}\text { U.P. } \\
(3 \%)\end{array}$ & $\begin{array}{l}\text { Bihar } \\
(3 \%)\end{array}$ & \\
\hline $\begin{array}{l}\text { Orissa } \\
(54 \%)\end{array}$ & $\begin{array}{l}\text { M.P. } \\
(22 \%)\end{array}$ & $\begin{array}{c}\text { Tamilnadu } \\
(17 \%)\end{array}$ & $\begin{array}{c}\text { Punjab } \\
(2 \%)\end{array}$ & $\begin{array}{c}\text { Haryana } \\
(2 \%)\end{array}$ & \\
\hline $\begin{array}{l}\text { Bihar } \\
(54 \%)\end{array}$ & $\begin{array}{c}\text { Tamilnadu } \\
(21 \%)\end{array}$ & $\begin{array}{l}\text { Punjab } \\
(14 \%)\end{array}$ & $\begin{array}{l}\text { Bihar } \\
(2 \%)\end{array}$ & $\begin{array}{l}\text { U.P. } \\
(1 \%)\end{array}$ & \\
\hline
\end{tabular}




\begin{tabular}{|c|c|c|c|c|c|}
\hline U.P. & $\begin{array}{c}\text { Punjab } \\
(45)\end{array}$ & $\begin{array}{c}\text { Bihar } \\
(6 \%)\end{array}$ & & & \\
\hline All India & All India & All India & All India & All India & \\
$(49 \%)$ & $(33 \%)$ & $(12 \%)$ & $(5 \%)$ & $(3 \%)$ & \\
\hline
\end{tabular}

Source: Singh, M.V. (2001)

Other micronutrients such as Fe are mainly deficient in Karnataka (35\%), H.P. (27\%), Maharastra (24\%), Haryana (20\%), Tamilnadu (17\%), and Punjab (14\%). Deficiency of $\mathrm{Mn}, \mathrm{Cu}$ and $\mathrm{Mo}$ is also emerging as the results of soil tests are being available from different parts of the country. Intensive soil testing is required to documents the actual status of micronutrients. General symptoms of micronutrients are presented in Table2.

Table .2: General symptoms of micronutrients deficiency in crop plants

\begin{tabular}{|c|c|}
\hline Micronutrients & Symptoms \\
\hline Zn & $\begin{array}{c}\text { Deep yellowing of whorl eaves (cereals).dwarfing (rosette) and yellowing of growing points of } \\
\text { leaves and roots (dicot).Rusting in strip on older leaves with yellowing in mature leaves. Leaf } \\
\text { size reduced. Main vein of leaf or vascular bundle tissue becomes silver-white and marked } \\
\text { strips appear in middle of leaves. }\end{array}$ \\
\hline $\mathbf{C u}$ & $\begin{array}{l}\text { Yellowing of young leaves. Rolling and dieback of leaf tips. Leaves are small. Tillering is } \\
\text { retarded. Growth is stunted. }\end{array}$ \\
\hline $\mathbf{F e}$ & $\begin{array}{l}\text { Interveinal yellowing of younger leaves with distinct green veins. Entire leaves become dark } \\
\text { yellow or white with severe deficiency and leaves border turns brown and die. }\end{array}$ \\
\hline Mn & $\begin{array}{c}\text { Interveinal tissue becomes light green with veins and surrounding tissue remaining green on } \\
\text { dicot (Christmas tree design) and long interveinal leaves streaks on cereals. Develop necrosis } \\
\text { in advance stage. }\end{array}$ \\
\hline B & $\begin{array}{l}\text { Death of growing points of roots and shoots. Failure of flower buds to develop. Blackening } \\
\text { and death of tissues especially the cambium tissues. }\end{array}$ \\
\hline Mo & $\begin{array}{c}\text { Mottled pale appearance in young leaves. Bleaching and withering of leaves and sometime tip } \\
\text { death. Legumes suffering molybdenum deficiency have pale green to yellowish leaves. } \\
\text { Growth stunted. Seed production is poor. }\end{array}$ \\
\hline Cl & $\begin{array}{c}\text { Reduce leaf size. Yellowing, bronzing and necrosis of leaves. Root reduced in growth and } \\
\text { without hairs. }\end{array}$ \\
\hline $\mathbf{N i}$ & $\begin{array}{l}\text { Chlorosis of newest leaves. Ultimately leads to necrosis of meristems .Reduced germination } \\
\text { and seedling vigor (low seed viability). }\end{array}$ \\
\hline Co & $\begin{array}{c}\text { Diffuse yellowing in leaves. Young shoots and younger leaves have severe localized marginal } \\
\text { scorching. }\end{array}$ \\
\hline
\end{tabular}

Source: Fageria et al. (2002)

\section{ROLE OF MICRONUTRIENTS}

ZINC (Zn)

Flower formation: Zinc is crucial in flower formation. i.e. Canola. Zinc acts like "Antifreeze" in the plant to give early and late frost protection. Zinc controls the synthesis of many plant growth regulators. Animals deficient in Zinc require twice as much feed to attain the same weight. Zinc is unavailable in high $\mathrm{pH}$ soils. Zinc improves germination rate and plant vigor.

\section{COPPER $(\mathbf{C u})$}

www.ijeab.com
Plant disease prevention: $\mathrm{Cu}$ is important in plant disease prevention. - Plant Diseases - i.e.: Net Blotch, Ergot and Pig Tailing. $\mathrm{Cu}$ affects lignin building qualities and is crucial in preventing lodging. $\mathrm{Cu}$ greatly affects kernel size and kernel weight.

\section{IRON (Fe)}

Chlorophyll formation: Iron is required for the formation of chlorophyll in the plant. Iron is essential for plant respiration, photo-synthesis and symbiotic nitrogen fixation. Iron along with Molybdenum help plants fix atmospheric 
NITROGEN out of the air. Also keep in mind that the air is $78 \%$ Nitrogen \& all plants can fix Nitrogen out of the air. Most soils in Western Canada are sufficient in iron.

\section{MANGANESE (Mn)}

The element of life: NO MANGANESE $=$ NO LIFE. Mn assists Iron in Chlorophyll production. Mn affects lignin building qualities and is critical in preventing lodging \& disease.

BORON (B):

In sugar mover: Boron moves plant sugars up and down the plant daily.

Cell development: Boron functions in plants in the differentiation of meristematic cells. Without Boron, cells may continue to divide, but structural components are not differentiated.

Missing seeds: At the top and the bottom of the pod is a hormone called GBBA. This hormone must move in the pod to fertilize each and every seed in that pod. No GBBA no seed. The nutrient that moves GBBA throughout the pod is Boron along with mainly Phosphorus, Manganese, Calcium and other nutrients. Remember boron along with Phosphorus moves sugars in the plant daily, so if there is an interruption of this or a lack of nutrients - the seed does not become fertilized so therefore no seed.

\section{MOLYBDENUM (Mo)}

Plant nodulation: The most miss understood micronutrient, but one of the most important. Without Mo plants cannot transform nitrogen into amino acids and legumes cannot symbiotically fix atmospheric nitrogen. Mo is very important for plant nodulation (Peas, Beans, Alfalfa).

\section{FUTURE ASPECTS}

There is an urgent need to increase the facilities of micronutrients analysis with qualified and trained personnel able to guide sampling techniques, take up the job of analysis and fertilizer recommendation effectively. Micronutrients deficiency in crop production is increasing with intensive cultivation. It has assumed importance because micronutrients deficiencies are identified as one of the key barrier in augmenting productivity of crops. Therefore, a well planed systematic and focused basic and strategic research work is need to be carried out to suggest its need, economic use of fertilizers and measures to enhanced fertilizer use efficiency.

\section{REFERENCES}

[1] Fageria, N. K.; Baligar, V. C.; Clark, R. B.(2002) Micronutrients in crop production. Advances in Agronomy, New York, v. 77, p. 189-272

[2] Singh, MV (2001) Evaluation of micronutrient stocks in different agro ecological zones of India. Indian J.Fertilizer 46:25-42.

[3] Singh, MV (2006) Micronutrients in crops and in soils of India. In. micronutrients for global

[4] crop production. (Ed. BJ Alloway), Springer.Business 